\title{
Var der dødsstraf for at hugge tønde eller tager Otto Kalkar fejl?
}

Af Jørn Mфller

»Forvar eder at $\mathrm{i}$ iche sidde natthen offuer oc slemme, alle natdriche oc utilbørlig nathvecht, som er huægehors, huidebørn, jullebuch, huggetønde, daartønd i brøllup oc andet saadant er altsammen afflagt, til landzting under kongenß sværdtt, huo der findes met.«

- Sådan skriver Peder Palladius i sin Visitatsbog som formaning til anstændighed under almuens sammenkomster og som kommentar til en gruppe folkelige lege, ${ }^{1}$ han finder anstødelige. Formaningen indicerer, at der efter reformationen skete en gevaldig skærpelse af den offentlige moral. ${ }^{2}$

Slår man efter i Otto Kalkars »Ordbog til det Ældre Danske Sprog «, ${ }^{3}$ vil man finde, at Kalkar angiver betydningen af »under kongens sværd « som ensbetydende med dødsstraf, og som eksempel henviser han netop til denne passus i Visitatsbogen. Det må man sige er en sanktion, der vil noget. En ting er, at $\varnothing$ vrigheden finder, at julelege, druk og andre fornøjelser er gået over gevind, og på den baggrund vil mane til ro og orden, men ligefrem dødsstraf??

Lad os prøve at tænke os om en ekstra gang og tage Otto Kalkar på ordet. I så fald foreligger der to muligheder: Den ene er, at der strammes op om sædeligheden, i en grad det er vanskeligt at forestille sig, når det kommer til at omfatte leg, som vi jo normalt betragter som noget ret uskyldigt. Den anden er, at legebegrebet har ændret sig, så vores fantasi har vanskeligt ved at forestille sig, hvilke obskøniteter, det i ældre tid omfattede.
Som regel tager man altid de legende bønders parti mod en despotisk statsmagt, der hårdhændet gennemfører en disciplinering af almuen for at fremme lydigheden og arbejdsomheden og for at komme almuekulturens antiautoritært-oprørske elementer til livs. Men lad os undersøge Peder Palladius' standpunkt og prøve at forstå sammenhængen fra den offentlige morals synspunkt. Det forudsætter en tolkning af legene, som sætter dem i en rimelig proportion til sanktionen dødsstraf.

For eksempel ved vi ikke, hvad »Hugge tønde« gik ud på. Det er ikke usædvanligt. Det gælder for mange andre gamle lege, at man kun kender navnet. ${ }^{4}$ Ingen kerer sig om at give detaljerede beskrivelser af noget, der er velkendt for alle i samtiden. Visse kilder angiver, at der er tale om en bryllupsleg, ${ }^{5}$ og vi skal altså til at forestille os, hvad der kunne forekomme ved bryllupper, når det gik så vildt til, at det var en sag for $\varnothing v$ righeden.

For at stemme sindet i disse baner, kan vi først kaste et blik på de excesser, som i vor tid har udviklet sig omkring "polterabend«-er. Enkelte af disse er endt med dødsfald, flere med at brudgommen er kommet så alvorligt til skade eller på anden måde er blevet forhindret, så man har måttet aflyse den følgende dags bryllup. Mange ender på skadestuen og adskillige polterabender bidrager på anden måde væsentligt til at forringe den følgende dags fest. Programmet består i, at enhver form 
for mådehold suspenderes, hvilket i grundtrækkene kommer til udfoldelse i tre projekter.

1. Umådeholden druk. Det gælder om for vennerne at få gjort ofret så sanseløst beruset, at det overgår deres egen tilstand. Formålet er, når natten er gået, at bringe ham hjem i en forfatning, så han ikke husker, hvor han har været, eller hvad han skal, og således at han kun kan gennemføre den følgende dag under store vanskeligheder. - Hvis han da bliver bragt hjem og ikke efterladt i detentionen, i zoo's abegrotte eller i en køje på Norgesbåden med enkeltbillet og uden penge.

2. Uvante præstationer under tvang. Det kan dreje sig om at have købt et bungyjump, et faldskærmsudspring, en vandskitur, rapelling eller lignende. Ofte måske harmløst, men forbundet med drikkeri, gruppepres og uvanthed alligevel noget, hvor man kan komme galt af sted. At leje en motorbåd, sejle et par sømil fra land og plumpe det nøgne offer i vandet med besked om, at nu kan han se, om han kan svømme hjem, er en grov spøg og også en kriminel handling, - i hvert fald hvis det går galt.

3. Seksuelle eskapader. Eftersom ægteskabet i denne sammenhæng repræsenterer et afkald på seksuel frihed, gælder det om for vennerne at sikre den kommende ægtemand mulighed for erotisk eskapade ved at tage ham til strip-tease, sørge for escortpige(r), få ham indlogeret på bordel, massageklinik, eller hvad man nu kan hitte på af aktiviteter, som ikke alle ligger inden for lovgivningens rammer.

Skønt det er interessant, skal der ikke i denne sammenhæng gøres overvejelser over, hvad det er for grundlæggende meka- nismer, der kan bringe en polterabend til at gå over gevind, hvad det er, der suspenderer vennernes (og på en anden måde også den vordende ægtefælles) bånd og hæmninger og kan få situationen til at eksplodere $\mathrm{i}$ et orgie af ondskabsfuldhed, ydmygelser og skadefryd. Til sammenligning med Palladius's bryllupsleg skal det blot konstateres, at spøgefuldhederne i forbindelse med bryllup også i dag kan komme i konflikt med straffelovens paragraffer om forstyrrelse af den offentlige orden, utugt, legemsbeskadigelse eller - i værste fald uagtsomt manddrab.

Lad os herefter vende tilbage til »Hugge tønde« og spekulere på, hvilke strafbare handlinger, man i fuldskab og grov kådhed for 500 år siden kunne betragte som leg. Navnet på en leg er ofte skabt gennem analogi med fænomener fra dagliglivet. I »Male kaffe« giver man hinanden en svingtur, der med lidt god vilje ligner den måde, kaffekværnen drejes på. I »Male peber « udsætter man hinanden for en lidt voldsommere behandling end $\mathrm{i}$ »Male kaffe«, og analogien går derfor til peberkværnen. At »Veje salt « er heller ikke videre behageligt, men bevægelsen ligner skålenes i en skålvægt.

Slår man op i »Ordbog over det Danske Sprog«(ODS), finder man ikke sammensætningen 'hugge tønde'. Der er ikke noget dagligdags fænomen, ingen foreteelse som dækkes af begrebet, og det indgår ikke i bødkerens fagsprog. Skifter man derimod udtrykke 'hugge' ud med det beslægtede 'slå' eller 'stikke', er der bid: 'slå katten af tønden', 'slå tappen af tønden’, 'stikke (eller 'slå') øllet/vinen an', 'stikke (eller 'slå’) en tønde an', 'slå tappen i tønden'. »Slå katten af tønden« er en fastelavnsleg, og derfor fanges vores bevidsthed af en lignende aktivitet, når vi skal give mening til »Hugge tønde«, men vi kan ikke finde 
noget, der ligner i forbindelse med bryllupper, så måske er det et vildspor.

Ved bryllupper bliver der derimod ofte slået nogle tønder $\varnothing 1$ eller vin an. Det er fagsprog og ikke alment forståeligt nutildags, hvor vi som regel får drikkevarerne leveret i flasker, og det skal derfor forklares: En øltønde er forsynet med et hul på »maven « med en prop i. Det er dér, man fylder tønden, og man er ligeledes nødt til at tage proppen ud, når man senere skal tappe af tønden, men det er kun for at kunne udligne trykket i tønden. Det er nemlig ikke dérfra, man skænker øllet. Dertil har man et andet hul i tøndens bund, spunshullet. Det er ved leveringen også forsynet med en træprop, spunsen, som slutter helt tæt, og som går i ét med bunden. Tønden skal nu udstyres med en hane, hvorfra man kan tappe $\varnothing$ llet - en tap. Denne operation, hvor man slår spunsen ind i tønden og dermed 'slår tappen i tønden', hedder også 'at slå (eller 'stikke') tønden an'.

Næste led i tankegangen må så være, om man kan finde en leg, som af $\varnothing$ vrigheden kan have været anset for usædelig, og som samtidig viser træk, der er analoge med den beskrevne operation. Det er ikke så svært: tappen i tønden kan være noget med samleje, og ODS kommer os til hjælp: 'at slå hul på tønden' kan således betyde 'at gøre barsel', ODS citerer endvidere Moths ordbog for 'at slå tønden an' i overført betydning kan bruges »om en Pige, der lader sig besove og siden bruger Handverket« (Moth T 260). Det udtryk er i sig selv en smule uklart, men kan kan f.eks. forestille sig, at det i forbindelse med prostitution er attraktivt for kunden at få en pige, der er debutant, og dermed altså få det privilegium »at slå tønden an«.

Hvis udtrykket 'hugge tønde' er analogt med denne overførte betydning af 'slå tønden an’, skal vi således for at forstå, hvad navnet på legen dækker, til at kigge nærmere på utugt - at lade sig besove eller at blive besovet i forbindelse med bryllupper.

Fra folkeviserne kender vi historien om Ebbe Skammelsøn, der vender hjem fra tjeneste i kongens gård og opdager, at hans trolovede, Adelus og hans bror, Peder, ja, hele familien på det skammeligste har bedraget ham, og at Peder nu er i færd med at holde bryllup med fæstemøen. Vi hører, at selskabet med Ebbe i spidsen, fører bruden til brudehus, og at han på vejen foreholder hende, at de er trolovede. Da hun ikke vil flygte med ham og ikke ændre brylluppet, slår han hende ihjel. Derefter går han tilbage til stenstuen, hvor der festes, og søger at lokke Peder udenfor:

Hør du Peder Skammelsøn, du tøver alt for længe; bruden længes fast efter dig udi sin brudeseng.«

Af fejhed og for at formilde Ebbe, føjer Peder spot til skade ved at tilbyde Ebbe, at han kan få den ære at sove med bruden den første nat.

Mælte det Peder, hans broder, svared han alt så brat:

»Så gerne vil jeg dig unde at sove hos bruden i nat.«

Fra en moderne synsvinkel er det naturligvis helt uacceptabelt for Ebbe. Og også for samtiden må dette tilbud til den forelskede Ebbe have forekommet ubærligt, ellers var der ikke blevet nogen folkevise. Det, som volder besvær at forstå, er, hvordan Peder overhovedet kan komme på noget så rablende som dette tilbud. End ikke Peders fejhed gør det indlysende, hvor han skulle få tanken fra. Hvad enten alliancen mellem 
ham og Adelus er et praktisk arrangement, eller den er baseret på kærlighed, hvad nogle af folkevisens varianter går ind for, er tanken ikke nærliggende: I det første tilfælde er der tale om en krænkelse af den hellige ejendomsret, og i det andet af nogle hellige følelser. At det bliver i familien, gør blot tilbuddet yderligere bizart og vel også yderligere ulovligt efter såvel kirkelig som kongelig ret. Forslaget er simpelthen monumentalt absurd, med mindre der er former for præcedens i den folkelige tradition for at andre får lov (eller tager sig lov), inden brudgommen kommer til. Det kendes fra samfund, der lever på randen af muligheden for overlevelse, hvor der ikke er privat ejendom at beskytte, og hvor det er kollektivets, snarere end slægtens videreførelse, som er det eksistentielle grundlag. Her drejer det sig mere om, at kvinderne bliver gravide, end med hvem.

Fra det russiske livegenskab kendes det som en ret, at herremanden kunne forlange at besove bruden som den første, denne »jus primae noctis« er en ret man har taget sig også andre steder i Europa, men den er - bortset fra muligvis under den sydfranske og spanske feudalisme - næppe lovfæstet nogetsteds i Europa. I Danmark er denne »ret« angiveligt efter den folkelige overlevering blevet praktiseret i slutningen af 1700-tallet af den despotiske herremand til Dronninglund, brigadér Halling. ${ }^{6}$ Hvis denne ret har været praktiseret i middelalderens Danmark, bliver Peders tilbud forståeligt. Dumt og uden psykologisk indsigt, men indenfor mulighedens rammer.

Hermed nærmer vi os måske, hvad det vil sige at »Hugge tønde«. Skal man bringe det ind i en sammenhæng, hvor det er mere berettiget at forbinde det med leg, så må man nok gøre sig klart, at udannede, berusede bønders og karles måde at lave løjer på næppe har været den mest smagfulde, og at spørgsmålet, om hvorvidt den, det gik ud over, var indforstået, nok kunne være underordnet, jvf. den måde, som vennerne i dagens Danmark tér sig, når der er udsigt til polterabend.

Uden at kende de nærmere omstændigheder må vi således sige, at »Hugge tønde« i sin essens kunne bestå $i$ at besove bruden, inden brudgommen når så vidt. Om det har form af en kollektiv voldtægt, eller af, at en $\emptyset$ vrighedsperson gjorde krav gældende på »at slå tønden an«, kan vi ikke ud fra det foreliggende vide, men det måtte $\mathrm{i}$ givet fald være foregået under nogen folkelig accept og have haft en vis om ikke udbredt tradition, ellers ville Peder Palladius næppe kunne referere så lakonisk til fænomenet, som han gør, og det ville næppe være nødvendigt at minde om, at en sådan form for voldførelse fra samfundets side blev straffet med døden, hvis det kom til øvrighedens kendskab.

Hvis denne tolkning er rigtig, er det interessante ikke så meget fortidens reaktioner på barbarisk adfærd, som spørgsmålet, hvordan kirken har formået at sætte en smule skik på os, hvordan 1800-tallets romantiske billede af fortidens bønder har kunnet danne skabelon, i en grad så vi fuldstændig har »glemt « en sådan gammel leg, ja, fået et helt andet legebegreb.

Det er imidlertid tvivlsomt, om tolkningen er holdbar. Godt nok så lovgivningen meget strengt på fænomener som voldtægt og tyveri, og den beskrevne adfærd ville formentlig udløse dødsstraf, men Palladius nævner jo andre aktiviteter end huggetønde: Hvegehors, julebuk, hvidebjørn og dåretønde. De gængse tolkninger af disse lege er, at det drejer sig om løsslupne, til tider blasfemiske løjer eller grovkornet satire rettet mod såvel kirkelige som verdslige myndigheder. Skønt de således set fra $\emptyset \mathrm{v}-$ righedens side ikke er spor uskyldige, rum- 
mer de, såvidt man kender dem, ikke noget, der blot nærmer sig det ovenfor beskrevne barbari, og det må anses for tvivlsomt, om der kan præsteres en omtolkning af dem, som på overbevisende måde kan bringe dem i så voldsom en konflikt med datidens straffelov, at det skulle udløse dødsstraf. Heller ikke jule- og bryllupstraditionerne i $\varnothing v$ vrigt repræsenterer lovovertrædelser i en sådan målestok. ${ }^{7}$ Myndighederne $\varnothing$ nsker at begrænse, hvad de betragter som overdreven selskabelighed, med en luksus, et æderi, og ikke mindst et afsindigt drikkeri, der kunne ende i knivstikkeri, vold og slagsmål, endog med døden til følge. Godtfolk havde nok sværere ved at styre sig dengang, men det var ikke traditionerne i sig selv, der var omfattet af dødsstraffens alvor.

Det er heller ikke leg som sådan, Palladius langer ud efter. Tværtimod ser han med velbehag på, at børnelærdommen »drikkes« ind i børnene med »leg, lyst og glæde. $\ll^{8}$

Og han er formentlig helt på linje med Nationalsynoden, når den opfordrer degnene til, at de for at lokke ungdommmen til katekismusundervisning ved højtiderne lader »dennem siden høffuiskligen lege paa gaden $\ll .{ }^{9}$ Det er derfor sandsynligt, at der findes en anden forklaring på, at legene »er aflagt under kongens sværd « end Kalkars dødsstraf.

Middelalderens statstænkning byggede på to-sværdsteorien, ifølge hvilken den verdslige magt og kirken, kejseren og paven, hver havde fået et sværd overdraget af Gud, og således hver havde sin udøvende myndighed, - hver sin jurisdiktion. Luther opgav denne to-sværdsteori til fordel for teorien om det åndelige og det verdslige regimente. Teorien skelner mellem evangelium og lov, og indebærer at der ikke kan opstå modsætninger mellem kirken og det verdslige regimente i en stat, der er kristen: Guds rige er ikke af denne verden, hvor staten til gengæld er suveræn så længe den varetager omsorgen for de verdslige og institutionelle sider af kirkens virksomhed. ${ }^{10}$

Når Palladius henviser til kongens sværd, kunne det således enten tyde på, at to-sværdsteorien ikke er helt forladt, eller i hvert fald at det stadig er muligt at bruge udtrykket »kongens sværd « om den statslige myndighed. Hvad han billedligt siger er altså blot, at ikke alene er huggetønde syndigt, men det er også forbudt efter verdslig lovgivning, og det er jo noget helt andet, end at der er dødsstraf. Tuft mener i øvrigt at Palladius er fuld af løgn, ${ }^{11}$ idet Chr. 3.'s Reces af 1539 indebærer en betydelig lempelse af festforordningerne, som i øvrigt på intet tidspunkt eksplicit har forbudt de nævnte lege. Visitatsbogen dateres til omkring 1543, og Palladius kan næppe være i god tro. Sådanne forbud dukker først op under 1700-tallets pietistiske bølger. 


\section{Noter}

1. Palladius p. 144.

2. cf.: Tuft,. Det er hans hovedtese.

3. Kalkar, opslagsord »sværd «.

4. Grüner-Nielsen har fx. en liste p. 59.

5. Palladius: »Tractat om de Stykker, hvormed Guds Ord kan forfremmes og ved Magt holdes.« cit. efter Tuft p. 134.

6. Eilstrup et al. p. 56; Krigshistorisk Tidsskrft p. 7.

7. cf.: Lund, bd. 11 \& 12; Møller, bd. 1 \& 2.

\section{Litteratur}

Eilstrup, P. et al.: Vore gamle herregårde. Lademann u.å.

Grüner-Nielsen, H.: »Julestuer og Julestuelege i Danmark paa Holbergs Tid.«Særtryk af Sprog og Kultur Institut for Jysk Sprog- og Kulturforskning. Universitetsforlaget i Aarhus, København 1933.

Kalkar, Otto: Ordbog til det Ældre Danske Sprog (1300-1700). Universitets-Jubilæets Danske Samfund 1881-1925.

Krigshistorisk Tidsskrift 2(1995)31.
8. Palladius p. 95

9. Chr. 3, 1555, 12. Maj Forklaring af nogle Artikler i Kirkeordinansen, vedtagen paa Superintendentmødet (Nationalsynoden.) i Kjøbenhavn. cit. efter Tuft p. 135.

10. cf.: Korsgaard, Ove: Manus »Kampen om Lyset« Utrykt 1995.

11.Tuft p. 132.

Lund, Troels: Dagligt Liv i Norden, bd. XI og XII, 4. udg., København og Kristiania u.å.

Møller, J.S.: Fester og Højtider i Gamle Dage. I-II Holbæk 1929 \& 1933.

Ordbog over det Danske Sprog (ODS).

Palladius Peder: En Visitatz Bog. Udg. af Lis Jacobsen, København 1925.

Tuft, Karsten: Legealder og Levealder - Et Landskabsbillede 1 - 2. I: Tidsskrift for B $\varnothing$ rne- og Ungdomskultur. November/December 1992 nr. 25-26. Århus 1992. 